\title{
Productivity of Maize in The Marginal Dryland in East Nusa Tenggara Province - Indonesia
}

\author{
Yohanes Leki Seran ${ }^{1, *}$, Helena da Silva ${ }^{1}$ dan Nelson Kario ${ }^{1}$ \\ ${ }^{1}$ Researchers at Assessment Institute for Agriculture Technology East Nusa Tenggara (AIAT - ENT) \\ Jln Timor Raya Km 32, Kupang Nusa Tenggara Timur - INDONESIA.
}

\begin{abstract}
Topography in East Nusa Tenggara Province dominate by dryland and slope land. In the dryland farmers develop farming system of maize as a staple crop. Dryland potential for food crop in Bali and Nusa Tenggara reach 645,891 ha but have low fertile and low productivity of maize. Productivity of maize in East Nusa Tenggara Province only reach $2.7 \mathrm{ton} / \mathrm{ha}$. This is lower productivity if compare with average of national level and result of research. The objective of research is to get specific technology of maize cultivation in the marginal dryland. This research was conducted in Kupang District as long as dry season at 2019. In this research apply three technology in maize cultivation. There were consist of (1) Farming system of maize that Apply recommendation chemical fertilizer + manure, (2) Farming system of maize that apply recommendation chemical fertilizer (Urea and NPK), (3) Farming system of maize that have no apply chemical fertilizer and manure. The Result of this research show that productivity of maize can reach 5.6 ton/ha on technology recommendation chemical and manure fertilizer.
\end{abstract}

\section{Introduction}

Farming system was developed by farmers in the marginal dryland as a resource for fulfill food security along one year, but sometime availability of food insufficiently for the time. Its caused of technology that farmers apply to the food crop farming system unsuitable with recommendation technology, physical of marginal land with less fertile, dry climate with short period of rainy season will happen drought for a long time. Complication of them create low productivity of food crop [1].

Amount Dryland in Indonesia reach 115.4 million ha. But dry land potential for agriculture reach 80.1 million ha while unsuitable dryland for it reach 35.3 million ha. Total dry land potential for agriculture especially food crop in Bali and Nusa Tenggara reach 645,891 ha [2]. According to [3] that East Nusa Tenggara Province had 2.9 million ha dryland and dry climate, it is widest region in Indonesia. All of it has characteristic dryland and low fertile. [4] show that dryland have shallow soil solum in Timor island - East Nusa Tenggara Province with lower fertile. Beside physical condition in Timor, farmers face an extreme climate with the rainfall below $1.500 \mathrm{~mm} /$ year [5]. Into the two condition farmers

\footnotetext{
* Corresponding author: lekialeks@gmail.com
} 
are running their activity to produce maize as a staple food. So productivity of maize that farmers get from their farming was lower. [6] had proven that maize productivity in marginal dryland was influenced by climate.

Productivity of maize as a food crop in East Nusa Tenggara Province only reach 2.7 ton/ha [7]. This is lowest productivity if be compared with National average and result of research. According to the result research of $[8,9]$ show that maize productivity particularly Hybrid of Nasa 29 can reach $8-10$ ton/ha. This research be conducted in the rain field with apply recommendation technology and use groundwater for irrigating.

However when this recommendation technology should be applied in the marginal dryland which always happen drought, farmers face the new challenges in their farming. But for maintaining productivity of maize especially hybrid Nasa 29 in the marginal dryland is required suitable technology for decreasing risk which caused by the climate change. Suitable technology for this condition are use organic fertilizer. Apply this technology for creating a conducive condition for maize growth to produce high productivity of food crop particularly maize crop.

The objective of this research is to get specific technology of maize cultivation in the marginal dryland.

\section{Material and method}

This research was conducted in Talnaku Village, Kupang District as long as dry season at 2019. Determining site selection base on (1) Most of the Location research is marginal dryland and topography of land is slope (2) Available water resource for irrigating the maize crop (3) Cooperative of farmers group to conduct this research. This research use farming system method with involve the farmers into the application technology. This research is conducted in the farmer's farm, by the farmers and join with the farmers, to apply the technology [10].

In this research was apply three technology on slope land. The slope land (S) consist of: (1) up land of slope, (2) middle land (3) under land of slope. Treatment of the research are verification technology method (T) which consist of (1) Farming system of maize that apply recommendation chemical fertilizer and manure, (2) Farming system of maize that apply recommendation chemical fertilizer (Urea and NPK), and, (3) Farming system of maize that have no apply fertilizer both manure and chemical fertilizer [11]. Combination of treatment showed at table 1.

Table 1. Combination of treatment Research (Maize Farming Technology) in Talnaku VillageKupang District

\begin{tabular}{|l|l|l|l|}
\hline Technology (T) & $\begin{array}{l}\text { Apply } \\
\text { recommendation } \\
\text { chemical fertilizer } \\
\text { (Chemical fertilizer) } \\
\text { + manure }\end{array}$ & $\begin{array}{l}\text { Apply } \\
\text { recommendation } \\
\text { fertilizer (Chemical } \\
\text { fertilizer) }\end{array}$ & $\begin{array}{l}\text { Farming } \\
\text { system of } \\
\text { maize that } \\
\text { have no apply } \\
\text { fertilizer }\end{array}$ \\
\hline Up land of slope, & S1T1 & S1T2 & S1T3 \\
\hline $\begin{array}{l}\text { Middle land of } \\
\text { slope S2T1 }\end{array}$ & S2T2 & S3T3 \\
\hline $\begin{array}{l}\text { Under land of } \\
\text { slope }\end{array}$ & S3T1 & S3T2 & S3T3 \\
\hline
\end{tabular}

Information: Each technology are applied in three replication. 


\subsection{Operational procedure}

Implementing this research follow some procedure that are water irrigation system, land preparation, planting (row planting), fertilizer, weed control, pest and disease control and harvest. For supporting to the maize farming should build water management system.

Step 1. Building Water irrigation system. Some activity in this step were to clean around the water resource, build the water tub and then installation pipe for irrigating the farm.

Step 2. Land preparation. Land preparation for maize farming system as follows clean bushes, apply herbicide to kill the grasses and bushes and then make planting hole and apply manure (special for first technology).

Step 3. Planting. Plant arrange in the farm were done through make row planting. Row planting in this research use $75 \mathrm{~cm} \mathrm{X} 40 \mathrm{~cm}$. On the each hole planted 2 seed of maizer. It is described as follows Figure 1.

\begin{tabular}{|c|c|c|c|c|c|}
\hline $\mathbf{X X}$ & $\mathbf{X X}$ & $\mathbf{X X}$ & $\mathbf{X X}$ & $\mathbf{X X}$ & $\mathbf{X X}$ \\
\hline & $75 \mathrm{~cm}$ & & & & \\
\hline $\mathbf{X X}$ & $\mathbf{X X}$ & $\mathbf{X X}$ & $\mathbf{X X}$ & $\mathbf{X X}$ & $\mathbf{X X}$ \\
\hline $\mathbf{X X}$ & $\mathbf{X X}$ & $\mathbf{X X}$ & $\mathbf{X X}$ & $\mathbf{X X}$ & $\mathbf{X X}$ \\
\hline & $40 \mathrm{~cm}$ & & & & \\
\hline $\mathbf{X X} /$ & $\begin{array}{l}\mathbf{X X} \\
\end{array}$ & $\mathbf{X X}$ & $\mathbf{X X}$ & $\mathbf{X X}$ & $\mathbf{X X}$ \\
\hline
\end{tabular}

Fig. 1. Maize lay out in the Farming

Step 4. Fertilizer. Fertilizer only apply to first and second farming system of maize and do not apply to the third farming system. Amount of manure per hectare as much $10 \mathrm{ton} / \mathrm{ha}$ and dose of recommendation fertilizer as much $200 \mathrm{~kg} / \mathrm{ha}$ urea, and $200 \mathrm{~kg} / \mathrm{ha} \mathrm{NPK}$.

Step 5. Weed control. Weeds growth in the farm of maize can disturb maize growth even decrease productivity of maize. Weed control can be done with apply selective herbicide in the farm. So after apply it, weeds become dry and die but maize keep going to grow.

Step 6. Pest control. Pest control should be done to avoid pest attack to the maize growth. Existence of pest in the maize farming can influence growth and productivity. Therefore must apply suitable pesticide for decrease or avoid attack of the pest.

Step 7. Harvest. When maize stalk have dried show that maize have matured physiology and as soon as it be harvested.

\subsection{Variables of observation and Data Analysis}

Some variables in this research consist of nutrient in the soil, maize growth, productivity and biomass. Data be collected on each stages growth of maize and then analyze with averages analysis.

\section{Result and discussion}

\subsection{Overview Research Location}

Base on the criteria to determinate location of this research then Talnaku Village fulfill to choose as site location. Site location of this research (Talnaku Village) dominant by 
marginal dryland. Topography of land are hilly and mountainous. Average of land have shallow solume, rocky stone land and low level of fertility. On this condition farmers running their dryland farming system. Land preparation for it be done by apply slash and burn technology. Usually farmers are doing on the dry season particularly along August until October every year. And then early rainy season farmers planting food crop especially maize, cassava, peanut and mungbean for providing food for a long year. For community in Timor - East Nusa Tenggara province, maize is a staple food crop so farmers planting one in large scale. However maize only planting one time per year. Agriculture practice like as describe above is known shifting cultivation.

Site research location have some water resources that are Oel Upun, Oelamisa, Oel Mella. The community in Talnaku village only use it for fulfill their daily needed and not for agriculture activity.

\subsection{Soil Analysis}

Nutrient of soil very important to be considered to apply fertilize in farm. Nutrient of soil in site research as below.

Table 2. Nutrient Content in the Soil of Talnaku Village- Kupang District

\begin{tabular}{|c|c|c|c|c|c|c|c|c|c|}
\hline \multirow[b]{2}{*}{ Slope } & \multirow[b]{2}{*}{ pH } & \multirow{2}{*}{$\begin{array}{l}\text { C } \\
\text { Organic } \\
(\%)\end{array}$} & \multirow{2}{*}{$\begin{array}{l}N \\
\text { total } \\
(\%)\end{array}$} & \multirow{2}{*}{$\begin{array}{l}\text { P2O5 } \\
(\%)\end{array}$} & \multirow{2}{*}{$\begin{array}{l}\mathbf{K} \\
(\%)\end{array}$} & \multirow[b]{2}{*}{ KTK } & \multicolumn{3}{|c|}{ Texture } \\
\hline & & & & & & & $\begin{array}{l}\text { Sand } \\
(\%)\end{array}$ & $\begin{array}{l}\text { Dust } \\
(\%)\end{array}$ & $\begin{array}{l}\text { Clay } \\
(\%)\end{array}$ \\
\hline Up land & 6.50 & 0.037 & 0.11 & 6.77 & 0.06 & 19.60 & 30.32 & 55.42 & 14.26 \\
\hline $\begin{array}{l}\text { Middle } \\
\text { land }\end{array}$ & 6.47 & 0.033 & 0.10 & 8.53 & 0.12 & 18.67 & 28.90 & 54.77 & 16.34 \\
\hline $\begin{array}{l}\text { Under } \\
\text { land }\end{array}$ & 6.40 & 0.027 & 0.08 & 5.35 & 0.05 & 20.13 & 35.12 & 55.34 & 9.54 \\
\hline
\end{tabular}

Source: Laboratory IAAT Analysis 2019.

Base on the table show that $\mathrm{pH}$ of the soil in Talnaku Village is neutral which ranges $\mathrm{pH}$ $6.40-6.50$. Nutrient content of phosphate as much 5.35 on under land of slope, 6.77 on the middle slope and 8.53 on the up land slope. On contrary nutrient content of nitrogen, kalium and $\mathrm{C}$ organic are very low. That way farms in Talnaku village need very attention to manage for gain high yield. Therefore apply organic matter or manure very important for creating conducive condition for the growth of maize.

\subsection{Climate in the site research}

Climate as one factor that very influence to maize growth in the marginal dryland farming. Existence of it very difficult to avoid in the farming. But this factor very importance. On the time climate change the rain uncertainly. Usually happen dry spell or season break during the rainy season, [12]. Climate condition in site research as long as 2019 as table 2.

Base on the table show that start from June to September 2019 (as long as four month) have no rain. This condition very difficult for all crops growth include maize crop. Rainfall rate in Kupang District $64 \mathrm{~mm} /$ year and number of rain days are 9.2 days. According to Kedang at al 2010 East Nusa Tenggara Province classified as the Region dry climate which have month of rain 3-4 month each year. Climate change with uncertain of rain and often happen period dray during the rainy season very disturb to all farming system management both directly and indirectly, so it threat to agriculture productivity. According to [14] that variability of climate as a phenomena of climate which often happen extreme climate for long duration. It's disturb to agriculture productivity. 
Table 3. Climate condition on 2019 in Kupang Regency

\begin{tabular}{|l|c|c|}
\hline Month & $\begin{array}{c}\text { Rainfall rate } \\
(\mathbf{m m} / \mathbf{m o n t h})\end{array}$ & Number of rain days \\
\hline January & 151 & 18 \\
\hline February & 97 & 12 \\
\hline March & 92 & 10 \\
\hline April & 27 & 3 \\
\hline May & 12 & 1 \\
\hline June & 0 & - \\
\hline July & 0 & - \\
\hline August & 0 & - \\
\hline September & 0 & - \\
\hline October & 7 & 2 \\
\hline November & 27 & 11 \\
\hline December & 110 & 17 \\
\hline Average & 64 & 9.2 \\
\hline
\end{tabular}

Source : [13]

\subsection{Performance of maize harvest Area in East Nusa Tenggara Province}

Maize crop had been developed by the Timor community as a staple food in dryland since last time. This crop very suitable with agroecology in Timor East Nusa Tenggara. Performance of maize harvest area for last five years from 2013 - 2017 in East Nusa Tenggara like as graphic below.

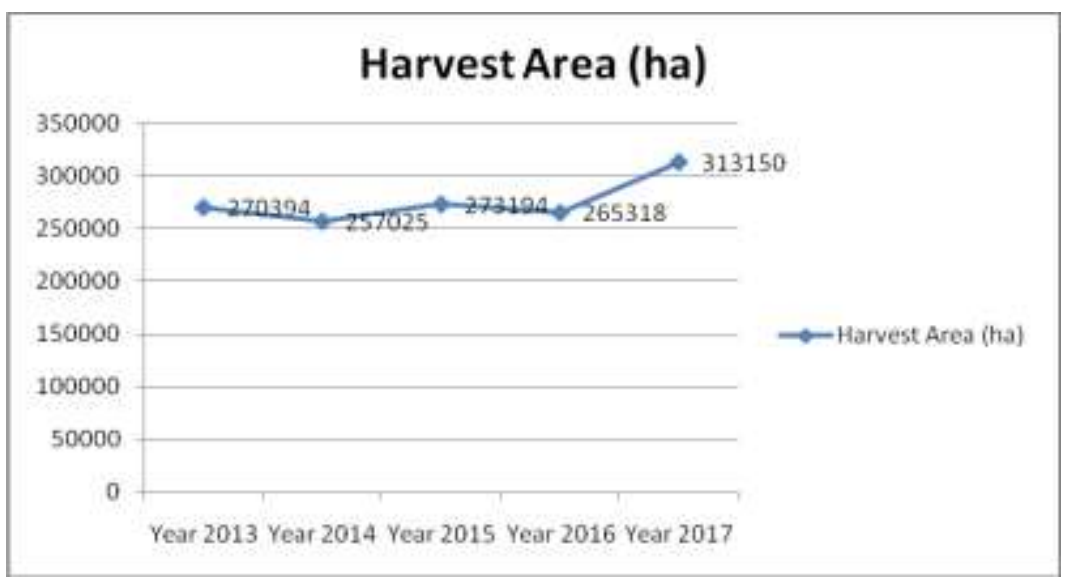

Source : [7]

Fig. 1. Maize harvest Area in East Nusa Tenggara Province

Base on the graphic show that maize harvest area in east Nusa Tenggara always increase every years because of farmers develop it as a staple food. In addition maize crop very suitable with characteristic agroecology zone in dryland. Therefore farmers always develop it although face more challenges.

\subsection{Maize Growth in the site Research}

Maize growth indicate capability of maize to absorb a number of soil nutrient, suitable to climate condition, and adaptable to land management. Result of this research show that maize growth very variation among treatments. Maize growth follow as bellow table 4 . 
Table 4. High plant $(\mathrm{cm})$ on the time harvest of Maize crops

\begin{tabular}{|l|l|l|l|}
\hline Treatment & I (Up Land of slope) & $\begin{array}{l}\text { II (Middle Land of } \\
\text { slope) }\end{array}$ & $\begin{array}{l}\text { III (Low Land } \\
\text { of slope) }\end{array}$ \\
\hline $\begin{array}{l}\text { Fertilizer } \\
\text { recommendation } \\
\text { manure }\end{array}$ & 174.2 & 179.4 & 180.6 \\
\hline $\begin{array}{l}\text { Fertilizer } \\
\text { recommendation }\end{array} \quad$ both & 159 & 164 & 177 \\
\hline $\begin{array}{l}\text { Unapplied } \\
\text { Fertilizer } \\
\text { recommendation and } \\
\text { manure }\end{array}$ & 120 & 124 & 133 \\
\hline
\end{tabular}

Base on the table show that high plant of maize reach $180.6 \mathrm{~cm}$ on the maize farming that apply fertilizer recommendation and manure. While high of maize crop in the maize farming which apply fertilizer recommendation reach $159-177 \mathrm{~cm}$ and high of maize crop in the maize farming which unapplied fertilizer recommendation and manure only reach $124-133 \mathrm{~cm}$. According to the Description of maize variety particularly hybrid Bima 19 URI show that high of maize up to $220 \mathrm{~cm}$ [15]. The maize farming both maize farming that apply fertilizer recommendation + manure and maize farming that apply fertilizer recommendation have capability to grow normally in the marginal dryland. On the maize farming that apply fertilizer recommendation + manure have highest plant because of capability manure to defense soil moisture and to create suitable condition or micro climate for maize on the climate change. Beside it on the maize growth abnormally in the farming that unapplied fertilizer recommendation and manure.

Other part of the maize which measuring is high plant until to cob. This variable show the position of the cob. High plant until to cob can be shown on the table below.

Table 5. High plant until to cob $(\mathrm{cm})$ on the time harvest of Maize crops

\begin{tabular}{|l|l|l|l|}
\hline Treatment & $\begin{array}{l}\text { I (Up Land of } \\
\text { slope) }\end{array}$ & $\begin{array}{l}\text { II (Middle Land } \\
\text { of slope) }\end{array}$ & $\begin{array}{l}\text { III (Low Land of } \\
\text { slope) }\end{array}$ \\
\hline $\begin{array}{l}\text { Fertilizer recommendation } \\
+ \text { manure }\end{array}$ & 80.2 & 82.4 & 83.4 \\
\hline Fertilizer recommendation & 70.4 & 74 & 78 \\
\hline $\begin{array}{l}\text { Unapplied both Fertilizer } \\
\text { recommendation and } \\
\text { manure }\end{array}$ & 40 & 42.8 & 47.2 \\
\hline
\end{tabular}

This table describe high and low of the cob position of maize. On the maize farming that not apply both Fertilizer recommendation and manure very lowest of cob position. And the highest position of cob is maize farming system that apply Fertilizer recommendation + manure.

\subsection{Productivity of Maize in the site Research}

Productivity of maize indicate the farming have capability to produce maize. Variability of maize product from this research depend applying of technology to the maize farming. Productivity of maize on the three technology which be applied on the research follow as table below. 
Table 6. Productivity of Maize (ton/ha)

\begin{tabular}{|l|c|c|c|c|}
\hline Treatment & $\begin{array}{c}\text { I (Up Land of } \\
\text { slope) }\end{array}$ & $\begin{array}{c}\text { II (Middle } \\
\text { Land of slope) }\end{array}$ & $\begin{array}{c}\text { III (Low Land } \\
\text { of slope) }\end{array}$ & Average \\
\hline $\begin{array}{l}\text { Fertilizer } \\
\text { recommendation } \\
\text { + manure }\end{array}$ & 5.33 & 5.60 & 5.87 & 5.6 \\
\hline $\begin{array}{l}\text { Fertilizer } \\
\text { recommendation }\end{array}$ & 4.00 & 4.00 & 6.93 & 4.98 \\
\hline $\begin{array}{l}\text { Unapplied both } \\
\begin{array}{l}\text { Fertilizer } \\
\text { recommendation } \\
\text { and manure }\end{array}\end{array}$ & 2.40 & 2.93 & 2.93 & 2.76 \\
\hline Average & 3.91 & 4.18 & 4.24 & \\
\hline
\end{tabular}

Base on the table show maize farming which applying Fertilizer recommendation + manure had highest productivity. The Result of this research show that productivity of maize can reach 5.87 ton/ha on maize farming which apply technology Fertilizer recommendation + manure. According to [16] that marginal dry land can be improved through apply organic matter as bokashi and [17] that apply fertilizer and green manure increase growth and yield of maize.

\subsection{Biomass of Maize}

Biomass of maize can be used for many propose such as organic mulch, compose, and feed of livestock. In the fact the farmers only a little use it in their farming even it be burnt on dry season. Amount biomass of maize which get from this research follow as.

Table 6. Dry Biomass (ton/ha) on the time harvest of Maize crops

\begin{tabular}{|l|c|c|c|}
\hline Treatment & $\begin{array}{c}\text { I (Up Land of } \\
\text { slope) }\end{array}$ & $\begin{array}{c}\text { II (Middle Land } \\
\text { of slope) }\end{array}$ & $\begin{array}{c}\text { III (Low Land of } \\
\text { slope) }\end{array}$ \\
\hline $\begin{array}{l}\text { Fertilizer } \\
\text { recommendation }+ \\
\text { manure }\end{array}$ & 1.334 & 1.867 & 2.934 \\
\hline $\begin{array}{l}\text { Fertilizer } \\
\text { recommendation }\end{array}$ & 1.334 & 1.334 & 1.867 \\
\hline $\begin{array}{l}\text { Unapplied both } \\
\text { Fertilizer } \\
\text { recommendation and } \\
\text { manure }\end{array}$ & 0.800 & 1.067 & 1.867 \\
\hline
\end{tabular}

Base on the table show that applying fertilizer recommendation and manure to the maize crop produce high biomass more than others. Weigh of maize biomass reach 2.934 ton/ha while not applied both fertilizer recommendation and manure produce low biomass. And [18] that biomass of maize can be increased by apply organic fertilizer and NPK fertilizer.

\section{Conclusion}

Base on the result of this research on the description can be concluded that maize farming system develop in marginal dryland face some challenges and to raise low productivity. In this research to prove that through apply recommendation chemical fertilizer and manure on the maize farming in marginal dryland can increase maize productivity up to 5.6 ton/ha. 
Acknowledgements. This paper was supported by Ms. Helena da Silva, SP, M.Si. as a supervisor that had given support to analysis and interpretation data of this research until to publish.

\section{References}

1. Mulyani A, Suwanda MH. Pengelolaan Lahan Kering Beriklim Kering untuk Pengembangan Jagung di Nusa Tenggara. J Sumberd Lahan (2020)

2. Irsalas and Ani Mulyani. Strategi Pengembangan Lahan Kering Berkelanjutan Untuk Mengatasi Kerawanan Pangan (2015)

3. Anny Mulyani MS. Karakteristik Dan Potensi Lahan Sub Optimal Untuk Pengembangan Pertanian Di Indonesia. J Sumberd Lahan (2013)

4. Tony Basuki, Helena da Silva, Wirdahayati R. Bamualim AB and S. Karakterisasi Zona Agroekologi (AEZ) di Nusa Tenggara Timur (1997)

5. Kedang Amir, Gerru Apolonaris H. Peta Sebaran Hujan Wilayah NTT (2010)

6. Hafif B, Meidaliantisyah M. Case Study of Maize Planting On Marginal Dry Land in The Rainy Season in Lampung. Int J Adv Sci Eng Inf Technol (2013)

7. BPS NTT. Provinsi Nusa Tenggara Timur Dalam Angka 2018 (2018)

8. Rihi Kornelis and Hosang. Pendampingan Perbenihan Jagung di Desa Oeteta Kabupaten Kupang (2018)

9. BPTP. Laporan Hasil Pengkajian BPTP NTT. Pendampingan PTT Jagung di Desa Oesao - Kabupaten Kupang. (2017)

10. Sumarno. Pengkajian Adaptif di lahan petani dengan orientasi pengguna (PAOP). BPTP Karangploso (1997)

11. Gomes GKA and AA Gomes. Statistical Prosedures for Agricultural Research, Second Edi. The International Rice Research Institute. Los Banos. Philippines (1983)

12. Faqih, A., Jamiko,D.J., Geru A. Keragaman dan Perubahan Iklim Nusa Tenggara Timur. UNDP-SPARC Project. Kementerian Lingkungan Hidup dan Kehutanan. Jakarta (2015)

13. BPS. Kabupaten Kupang Dalam Angka 2019 (2019)

14. Y Apriyana, E Purwandhini, Y Koesmaryono I Las. Dampak variabilitas iklim terhadap dinamika awal musim tanam padi di dua sentra produksi beras Jawa Barat. J Tanah dan Iklim 31 (2010)

15. Yuliana Aqil Muhamad and Rahmi Arva. Deskripsi Varietas Ungul. Balai Penelitian Tanaman Serelia. Maros (2014)

16. Karimuna L, Rahni NM, Boer D. The Use of Bokashi to Enhance Agricultural Productivity of Marginal Soils in Southeast Sulawesi, Indonesia. J Trop Crop Sci (2016)

17. Subaedah S, Aladin A, Nirwana. Fertilization of Nitrogen, Phosphor and Application of Green Manure of Crotalaria Juncea in Increasing Yield of Maize in Marginal Dry Land. Agric Agric Sci Procedia (2016)

18. Maswar, Soelaeman Y. Effects of organic and chemical fertilizer inputs on biomass production and carbon dynamics in a maize farming on ultisols. Agrivita (2016) 